\title{
Soil Attributes Using Different Agricultural Use Systems in the Rio Grande do Norte Semiarid, Brazil
}

\author{
Ana Karenina Fernandes de Sousa Ribeiro ${ }^{1}$, Jeane Cruz Portela ${ }^{1}$, Rafael Oliveira Batista ${ }^{1}$, \\ Carolina Malala Martins Souza ${ }^{1}$, Joseane Dunga da Costa $^{1}$, Phâmella Kalliny Pereira Farias ${ }^{1}$ \\ \& Tarcísio José de Oliveira Filho ${ }^{1}$ \\ ${ }^{1}$ Universidade Federal Rural do Semi-árido, Mossoró, Brazil \\ Correspondence: Jeane Cruz Portela, Universidade Federal Rural do Semi-árido, Av. Francisco Mota, 572-Bairro \\ Costa e Silva, CEP: 59.625-900, Mossoró, RN, Brazil. Tel: 55-(84)-996-933-669. E-mail: \\ jeaneportela@ufersa.edu.br
}

$\begin{array}{lrr}\text { Received: April 2, } 2018 & \text { Accepted: July 6, } 2018 & \text { Online Published: October 15, } 2018 \\ \text { doi:10.5539/jas.v10n11p190 } & \text { URL: https://doi.org/10.5539/jas.v10n11p190 }\end{array}$

\begin{abstract}
The semiarid region is extremely fragile to anthropogenic actions. Thus, the objective of this study is to evaluate the physical and chemical attributes of soils with different agricultural uses. The research was carried out in the municipality of Governador Dix-Sept Rosado. Fertility and physical analyses were performed. The results were interpreted by multivariate analysis. The soils that presented a eutrophic character were influenced by lithology. In the Cambissolo (Haplustepts), there was an increase in the limits of liquidity and plasticity due to the increase of the clay fraction and total organic carbon. By the particle size analysis, the profiles presented variations in textural classes. We concluded that the physical attributes moisture, liquidity limit, plasticity limit, clay plasticity index, thin sand and the chemical attributes $\mathrm{pH},(\mathrm{H}+\mathrm{Al}), \mathrm{V}$ and PST were the most sensitive for the distinction of environments. The studied areas presented acidity reactions to alkalinity with presence of $\mathrm{Al}^{3+},(\mathrm{H}+\mathrm{Al})$ and high salinity.
\end{abstract}

Keywords: multivariate Analysis, consistency, landscape soil ratio, plasticity index.

\section{Introduction}

The semiarid region has environmental variability, especially in relation to geological materials, relief, vegetation, and some important variations with respect to the climate. Due to such variability, there are significant soil differentiations in the environments that integrate the surface occupied by the Caatinga biome. Nevertheless, the soils of this region are intensely degraded mainly due to anthropic actions that do not take into account local peculiarities, making the region more susceptible to the processes of degradation.

As the rainfall regime decreases, less chemical weathering occurs, and lithology becomes increasingly prominent in the differentiation of soil characteristics and properties, reflecting in strong correlation with material of origin and influence of the relief (Coelho, 2016).

The evaluation of soil physical and chemical attributes is of extreme importance due to its sensitivity to changes in quality, since it may provide subsidies for the establishment of adequate systems of soil management and agricultural crops, contributing to the maintenance of agroecosystems.

Studies evaluating soil attributes in the western mesoregion of the state of Rio Grande do Norte (RN) are scarce since their quantification with different uses and environments, in an integrated way, is necessary for the understanding and the consequent adoption of practices appropriate to local particularities.

In view of the above, this study was carried out with the objective of evaluating the physical and chemical attributes of different agricultural uses, detecting the most sensitive attributes in order to identify the potentialities and/or restrictions for soil use and conservation in the mesoregion of the western part of the state of Rio Grande do Norte (RN) for the distinction between environments through the technique of multivariate analysis. 


\section{Method}

\subsection{Description of the Study Area}

The research was carried out in the municipality of Governador Dix-Sept Rosado in different soil classes. According to Köppen, the climate of this region is classified as hot semiarid with an annual average rainfall of $712 \mathrm{~mm}$ from February to May (Beltrão et al., 2005).

The study areas were defined as 01-Cambissolo (Haplustepts) area (Profile 1) (AC), 02-Eutrustox area (Profile 2) (AL), 03-Cambissolo 2 (Haplustepts 2) area (Profile 3) (AV) (Table 1).

Table 1. Coordinates of references of the classes of soils analyzed

\begin{tabular}{lll}
\hline & Coordinates & \multirow{2}{*}{ Soil class } \\
\hline South Latitude & West Longitude & \\
\hline $5^{\circ} 30^{\prime} 12.8^{\prime \prime}$ & $37^{\circ} 27^{\prime} 1^{\prime \prime}$ & Cambissolo (Haplustepts) (Profile 1) \\
$5^{\circ} 29^{\prime} 47.3^{\prime \prime}$ & $37^{\circ} 28^{\prime} 20.8^{\prime \prime}$ & Latossolo (Eutrustox) (Profile 2) \\
$5^{\circ} 10^{\prime} 1.91^{\prime \prime}$ & $37^{\circ} 14^{\prime} 2.86^{\prime \prime}$ & Cambissolo 2 (Haplustepts 2) (Profile 3) \\
\hline
\end{tabular}

The municipality of Governador Dix Sept Rosado has the profiles 1, 2 and 3: Cambissolo (Haplustepts) (Area (AC)), with local hyperxerophytic deciduous Caatinga vegetation, and at the time of collection there were planting of corn and sorghum; Latossolo (Eutrustox), with a native forest vegetation containing deciduous hyperxerophilic Caatinga; and finally, Cambissolo 2 (Haplustepts 2), with existing deciduous hyperxerophilic Caatinga vegetation.

\subsection{Analyses of Soil Chemical Attributes}

Soil collections for the research were carried out according to the Brazilian Soil Classification System (Santos et al., 2013) e Soil Taxonomy (Soil Survey Staff, 1999).

The chemical attributes evaluated were hydrogen potential $(\mathrm{pH})$ in water, electrical conductivity $(\mathrm{EC})$ in water, total organic carbon (TOC) by digestion of organic matter, exchangeable calcium content $\left(\mathrm{Ca}^{2+}\right)$ and exchangeable magnesium $\left(\mathrm{Mg}^{2+}\right)$ using the extractor potassium chloride, potential acidity $(\mathrm{H}+\mathrm{Al})$ using calcium acetate, and phosphorus (P), sodium $\left(\mathrm{Na}^{+}\right)$and potassium $\left(\mathrm{K}^{+}\right)$using Mehlich 1 extractor. Consequently, cation exchange capacity (CEC), base sum (BS) and base saturation (V) were calculated and analyzed according to [4]. They were interpreted according to the Manual of Recommendations for the use of correctives and fertilizers in Minas Gerais [14].

\subsection{Analyses of Soil Physical Attributes}

The particle size was obtained by the pipette method, using a chemical dispersant (sodium hexametaphosphate). Pre-treatments were performed on the samples of the diagnostic horizons that showed effervescence by adding $10 \% \mathrm{HCl}$ (Teixeira et al., 2017).

Soil consistency tests were determined according to Teixeira et al. (2017) based on liquidity limits (LL) using the Casagrande apparatus. The plasticity limit (PL) was determined by collecting representative samples of the central part of the soil shear in the metallic sphere of the equipment from the determination of the liquidity limit and forming a sphere, which was compressed on a glass plate until forming a cylindrical rod 3.0-4.0 mm in diameter without breaking or flowing. This procedure was performed in four replicates per horizon diagnosis for the respective soil classes. Gravimetric moisture was determined in plasticity in soil rods. The plasticity index (PI) was determined by the difference between (LL) and (PL).

\subsection{Statistical Analysis and Interpretation of Results}

Multivariate analysis techniques were used as the main tools, specifically Principal Component Analysis (Statistica, 2004), to distinguish the soils surveyed.

As a tool to distinguish areas of agricultural uses, diagrams of the main components (Factors 1, 2, 3, 4 and 5) were made for the physical attributes (grain size, consistency indexes) and chemical attributes ( $\mathrm{pH}, \mathrm{CE}, \mathrm{TOC}, \mathrm{P}$, $\left.\mathrm{K}^{+}, \mathrm{Na}^{+}, \mathrm{Ca}^{2+}, \mathrm{Mg}^{2+},(\mathrm{H}+\mathrm{Al}), \mathrm{BS}, \mathrm{V}, \mathrm{ESP}\right)$ together. From these data, two-dimensional diagrams were created to distinguish the areas of soil collection and vector projection diagrams in order to distinguish the attributes of the soil that most differentiated the areas surveyed. 


\section{Results and Discussion}

\subsection{Analysis of Chemical Attributes}

By analyzing the chemical attributes of the soils in the respective diagnostic horizons, it was verified that there was variation in $\mathrm{pH}$ values between the classes of soils, varying from 4.45 to 6.52 (Table 2).

The alkalinity occurs more naturally in arid and semiarid regions where, due to the low rainfall, the accumulation of salts, especially of calcium, magnesium and sodium carbonate, is among the exchangeable bases (Buckman, 1989). There was a pH variation of 4.45 to 5.34 in the Latossolo (Eutrustox) (Profile 2), showing acidity, which can be justified by its higher location in the landscape $(97 \mathrm{~m})$, favoring intense chemical weathering, with loss of the basic cations by leaching.

Table 2. Chemical attributes in the respective diagnostic horizons and soil classes

\begin{tabular}{|c|c|c|c|c|c|c|c|c|c|c|c|c|c|c|c|c|}
\hline Horizon Diagnosis & pH Water & $\mathrm{EC}$ & $\mathrm{P}$ & TOC & $\mathrm{Ca}^{2+}$ & $\mathrm{Mg}^{2+}$ & $\mathrm{K}^{+}$ & $\mathrm{Na}^{+}$ & $\mathrm{Al}^{3+}$ & $(\mathrm{H}+\mathrm{A})$ & BS & $\mathrm{t}$ & $\mathrm{CEC}$ & $\mathrm{V}$ & $\mathrm{m}$ & ESP \\
\hline 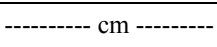 & & $\mathrm{ds} \mathrm{m}^{-1}$ & $\mathrm{mg} \mathrm{dm} \mathrm{m}^{-3}$ & $\mathrm{~g} \mathrm{~kg}^{-1}$ & $-\cdots$ & & & & $-\mathrm{cmol}$ & $\mathrm{c} \mathrm{dm}^{-3}-$ & & . & 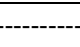 & & $\%$ & \\
\hline \multicolumn{17}{|c|}{ CAMBISSOLO (Haplustepts) (PROFILE 1) } \\
\hline $\mathrm{A}(0-10)$ & 6.00 & 0.56 & 470.59 & 15.65 & 7.05 & 2.39 & 0.63 & 0.02 & 0 & 3.14 & 10.10 & 10.10 & 13.24 & 76.3 & 0 & 0 \\
\hline $\mathrm{Bi}(10-45)$ & 6.44 & 0.70 & 137.47 & 10.18 & 8.10 & 1.93 & 0.35 & 0.04 & 0 & 2.81 & 10.41 & 10.41 & 13.22 & 78.7 & 0 & 0 \\
\hline \multicolumn{17}{|c|}{ LATOSSOLO (Eutrustox) (PROFILE 2) } \\
\hline $\mathrm{A}(0-13)$ & 5.34 & 0.48 & 115.47 & 27.71 & 4.45 & 1.04 & 0.19 & 0.01 & 0 & 3.47 & 5.68 & 5.68 & 9.15 & 62.1 & 0 & 0 \\
\hline $\mathrm{AB}(13-45)$ & 5.00 & 0.23 & 72.22 & 3.35 & 1.45 & 0.87 & 0.12 & 0.01 & 0 & 2.31 & 2.44 & 2.44 & 4.75 & 51.4 & 0 & 0 \\
\hline BA (45-87) & 4.45 & 0.54 & 88.91 & 3.20 & 1.40 & 0.30 & 0.12 & 0.04 & 0 & 2.15 & 1.86 & 1.86 & 4.01 & 46.4 & 0 & 1 \\
\hline B $(87-140)$ & 4.52 & 0.31 & 462.25 & 33.95 & 2.65 & 1.14 & 0.09 & 0.01 & 0 & 2.15 & 3.89 & 3.89 & 6.04 & 64.4 & 0 & 0 \\
\hline \multicolumn{17}{|c|}{ CAMBISSOLO 2 (Haplustepts 2) (PROFILE 3) } \\
\hline $\mathrm{A}(0-7)$ & 6.52 & 0.34 & 143.54 & 55.40 & 21.00 & 2.91 & 0.50 & 0.05 & 0 & 2.81 & 24.46 & 24.46 & 27.27 & 89.7 & 0 & 0 \\
\hline B (7-37) & 6.32 & 1.37 & 101.05 & 10.73 & 27.35 & 3.97 & 0.18 & 0.21 & 0 & 2.15 & 31.71 & 31.71 & 33.86 & 93.6 & 0 & 1 \\
\hline
\end{tabular}

Note. $\mathrm{pH}$ : hydrogen potential; EC: Electrical conductivity; $\mathrm{OC}$ : organic carbon; $\mathrm{Ca}^{2+}$ : calcium; $\mathrm{Mg}^{2+}$ : magnesium; $\mathrm{K}^{+}$: potassium; $\mathrm{Na}^{+}$: sodium; $\mathrm{Al}^{3+}$ : aluminum; $(\mathrm{H}+\mathrm{A})$ : potential acidity; $\mathrm{BS}$ : base sum; $\mathrm{t}$ : effective cation exchange capacity; CEC: potential cation exchange capacity; V: base saturation; m: aluminum saturation; ESP: exchangeable sodium percentage.

As for EC, it was observed that the highest amounts of salts were found in the subsurface in the profiles Cambissolo 2 (Haplustepts 2) (Profile 3) $\left(1.37 \mathrm{dS} \mathrm{m}^{-1}\right)$ and Cambissolo (Haplustepts) (profile 1) $\left(0.70 \mathrm{dS} \mathrm{m}^{-1}\right)$.

In arid and semi-arid regions, in addition to low rainfall, high evaporation tends to concentrate the salts on the soil surface, which is the most exploited layer by the root system of the crops (Batista et al., 2002).

The Latossolo (Eutrustox) (Profile 2) presented low and uniform EC values in the profile ranging from $0.23 \mathrm{dS}$ $\mathrm{m}^{-1}$ to $0.54 \mathrm{dS} \mathrm{m}^{-1}$, and may be justified by lithology, consisting of tertiary arenitic sediments of pre-Cambrian origin (Jacomine, 1971).

By evaluating the TOC (Table 2), the Cambissolo 2 (Haplustepts 2) (Profile 3) had the highest amount of it $\left(55.40 \mathrm{~g} \mathrm{~kg}^{-1}\right)$. This may be related to the shear area contributing to the values found. In the Latossolo (Eutrustox) (Profile 2), the presence of organic matter can be due to the binding of organic acids to chemical elements such as aluminum and manganese. In general, Caatinga soils are considered shallow, with a good fertility and deficiency in organic matter due to the decomposition influenced by the climatic (Linhares \& Gewandszbajder, 1998).

The phosphorus (P) levels in the evaluated soils were high. Silva et al. (2008) verified a high P content in cultivated areas in relation to native forest, according to the work under study. In relation to the distribution of the phosphorus of the profile, Kiehl and Lambais (1994) stated that this element's content is higher in the surface and decreases according to the depth.

By analyzing the profiles (Table 2) with respect to base saturation, there was a high base saturation, considered eutrophic (V > 50\%), except for the Latossolo (Eutrustox) (Profile 2). In Latossolo (Eutrustox), generally, the main limitation is a low natural fertility, because they are dystrophic soils with a low base saturation (EMBRAPA, 1997). 
The amount of $\mathrm{Ca}^{2+}$ was greater than $4 \mathrm{cmolc} \cdot \mathrm{dm}^{-3}$ in Cambissolo 2 (Haplustepts 2) (Profile 3) and Cambissolo (Haplustepts) (Profile 1) (Table 2), which can be considered as very good. This is due to the geology of the region, where soils are classified as Cretaceous of the group Apodi, limestone Jandaíra and Arenito Açu. This element, as Meurer reports (2000) promotes the flocculation of clays, besides contributing to an increase in the biological activity, which favors the aggregation of soil particles. Thus, it presents deficiency in infiltration, and consequently physical limitations on drainage. The material of origin (Jandaíra limestone) in the process of weathering dissociates calcium carbonate in the soil system. Because it is in a semiarid region, the environment presents a low weathering, irregular rainfall regime and high temperatures, becoming conditioning factors for the maintenance of exchangeable bases (Beltrão et al., 2005).

Cation exchange capacity was considered very good (CEC > 8) for Cambissolo (Haplustepts) (Profile 1) and Cambissolo 2 (Haplustepts 2) (Profile 3). Most CEC of these soils is occupied by essential cations such as $\mathrm{Ca}^{2+}$ and $\mathrm{Mg}^{2+}$ in function of the type of clay originating from the source material (Jandaíra limestone) with predominance of ilite (2:1), mica (2:1) and vermiculite (2:1). One can infer a greater natural fertility of these soils (Ronquim, 2010).

\subsection{Analyses of Soil Physical Attributes}

The results of the particle size distribution and its textural classification are presented in Table 3 . In general, the profiles under study presented variation in the textural classification. An increase in the subsurface clay fraction was observed for all soil classes.

Table 3. Distribution of particle size and its textural classification in the soil classes under study in the municipalities of RN

\begin{tabular}{|c|c|c|c|c|c|c|}
\hline \multirow{2}{*}{ Horizon Diagnosis $(\mathrm{cm})$} & \multicolumn{5}{|c|}{ Particle size distribution } & \multirow{2}{*}{ Textural Classification ( $\mathrm{SiBCS})$} \\
\hline & Coarse sand & Thin sand & Total sand & Silt & Clay & \\
\hline \multicolumn{7}{|c|}{ 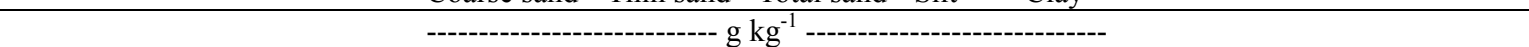 } \\
\hline \multicolumn{7}{|c|}{ CAMBISSOLO (Haplustepts) (PROFILE 1) } \\
\hline $\mathrm{A}(0-10)$ & 339.75 & 269.96 & 609.72 & 74.71 & 315.56 & Sandy clay loam \\
\hline $\mathrm{Bi}(10-45)$ & 304.13 & 212.83 & 516.96 & 81.86 & 401.18 & Sandy clayey \\
\hline \multicolumn{7}{|c|}{ LATOSSOLO (Eutrustox) (PROFILE 2) } \\
\hline $\mathrm{A}(0-13)$ & 480.37 & 359.37 & 839.74 & 47.51 & 112.73 & Sandy loam \\
\hline $\mathrm{AB}(13-45)$ & 466.97 & 381.75 & 848.72 & 2.74 & 148.53 & Sandy loam \\
\hline BA $(45-87)$ & 365.19 & 302.20 & 667.39 & 44.32 & 288.28 & Sandy clay loam \\
\hline $\mathrm{B}(87-140)$ & 270.70 & 188.72 & 459.42 & 98.61 & 441.96 & Sandy clay loam \\
\hline \multicolumn{7}{|c|}{ CAMBISSOLO 2 (Haplustepts 2) (PROFILE 3) } \\
\hline $\mathrm{A}(0-7)$ & 280.95 & 214.94 & 495.89 & 178.60 & 325.49 & Sandy clay loam \\
\hline $\mathrm{B}(7-37)$ & 353.92 & 113.14 & 467.06 & 113.93 & 418.99 & Sandy clayey \\
\hline
\end{tabular}

The areas surveyed had high clay contents, $418.99 \mathrm{~g} \mathrm{~kg}^{-1}$ in Cambissolo 2 (Haplustepts 2) (Profile 3), $401.18 \mathrm{~g}$ $\mathrm{kg}^{-1}$ in Cambissolo (Haplustepts) (Profile 1) and $441.96 \mathrm{~g} \mathrm{~kg}^{-1}$ in the Latossolo (Eutrustox) (Profile 2). The physical-chemical properties of the clay fraction define the high specific surface area, the development of surface electric charges, where cationic exchanges occurs, as well as a greater retention of water in the soil profile. However, they are more susceptible to compaction, being easily modified by anthropic behavior related to the traffic of animals and machinery in the areas, without observing essential criteria regarding inorganic fractions and soil water content due to the predominance of micropores (Santos et al., 2009). In the Latosol (Profile 2), it was verified a higher concentration of the sand fraction, which may be related to the location in the landscape (high). High values of sand fraction were found in forest fragment soils in comparison with degraded areas, being the expressive quantity on the Surface (Nogueira, 2000).

By analyzing Table 4, referring to consistency, it was observed that in Cambissolos (Haplustepts) (Profile 1 and 3 ) there was an increase in the liquidity and plasticity limits due to the increase in clay content, especially the first profile, with a maximum value of 33.30 for the Cambissolo 2 (Haplustepts 2) (Profile 3) and 21.40 for the Cambissolo (Haplustepts) (Profile 1), thus reflecting extreme LL and PI values.

In the Latossolo (Eutrustox) (Profile 2), there was a decrease in these limits in function of the sandy and loam textures (horizons $\mathrm{A}$ and $\mathrm{AB}$ ) and sandy clayey (BA and $\mathrm{B}$ horizon), thus favoring the infiltration of water in the soil, reflecting in smaller values of PL, lower values when compared to the other profiles. The Latossolo 
(Eutrustox), due to the presence of a similar clay content between the latossolic A and B horizons at greater depth, facilitate the infiltration of water, which reduces erosion.

According to the classification suggested for plasticity index (PI) by Caputo (1987), all classes on the surface were moderately plastic $(7<\mathrm{PI}<15)$, as well as Cambissolo 2 (Haplustepts 2$)$ (Profile 3 ) in the subsurface. The subsurface Latossolo (Eutrustox) (Profile 2) and Cambissolo (Haplustepts) (Profile 1) were classified as poorly plastic $(1<\mathrm{PI}<7)$.

There were increases in the liquidity and plasticity limits with the increase of the clay fraction and total organic carbon, and a decrease in the increase of the total sand fraction in the Cambissolo 2 (Haplustepts 2) (Profile 3). This is due to the predominance of clay minerals, with a higher specific surface area and an increase in the clay fraction's ability to interact with water and increase the lubricating effect of this clay, resulting in the rearrangement of smaller particles on top of each other, which increased the plasticity index.

The increase in values of plasticity limits in the Cambissolo (Haplustepts) (Profile 1) shows a special care regarding soil management, since the interval for the preparation is reduced due to changes in the types of consistency governed by soil moisture and clay content in the studied soil class.

The characteristics of the profile of Cambissolo (Haplustepts) (Table 3) shows that it is an underdeveloped soil with an incipient $\mathrm{B}$ horizon. It presents a small increase of clay from the horizon $\mathrm{A}$ to $\mathrm{Bi}$, and has good agricultural potential regarding fertility, although it has as physical restrictions slow drainage and infiltration. Because it is shallow, there is a need for conservation practices because of the greater susceptibility to erosion processes.

Table 4. Values of moisture, plasticity limit, liquidity limit and plasticity index of soil profiles

\begin{tabular}{|c|c|c|c|c|}
\hline Horizon Diagnosis $(\mathrm{cm})$ & Gravimetric Humidity & Plasticity Limit & Liquidity limit & Plasticity Index \\
\hline & ---------- $\mathrm{g} \mathrm{g}^{-1}$--------- & \multicolumn{3}{|c|}{---------------------------------- g 100 g $^{-1}$---------------------------------- } \\
\hline \multicolumn{5}{|c|}{ CAMBISSOLO (Haplustepts) (PROFILE 1) } \\
\hline $\mathrm{A}(0-10)$ & 0.25 & 17.20 & 24.30 & 7.10 \\
\hline $\mathrm{Bi}(10-45)$ & 0.25 & 21.40 & 25.60 & 4.30 \\
\hline \multicolumn{5}{|c|}{ LATOSSOLO (Eutrustox) (PROFILE 2) } \\
\hline $\mathrm{A}(0-13)$ & 0.22 & 55.20 & 34.20 & 8.70 \\
\hline $\mathrm{AB}(13-45)$ & 0.16 & 14.60 & 11.90 & 2.70 \\
\hline BA $(45-87)$ & 0.22 & 18.60 & 21.50 & 2.90 \\
\hline B $(87-140)$ & 0.31 & 13.40 & 31.10 & 17.70 \\
\hline \multicolumn{5}{|c|}{ CAMBISSOLO 2 (Haplustepts 2) (PROFILE 3) } \\
\hline $\mathrm{A}(0-7)$ & 0.23 & 26.30 & 39.00 & 12.70 \\
\hline B (7-37) & 0.43 & 33.30 & 44.60 & 11.20 \\
\hline
\end{tabular}

The Cambissolos (Haplustepts) (Profile 1 and 3) (Table 3) show a significant restriction to water percolation due to the high clay content. Its drainage is inefficient and its main limitations are related to the use of machines in the rainy season, low infiltration of water and slow drainage, favoring fluidity (superficial flow). It does not present silt in this layer, because it is an old soil, due to the intense chemical weathering.

In the Latossolo (Eutrustox) (Profile 2) (Table 3), a greater effective depth $(0-140 \mathrm{~cm})$ was verified, not presenting silt within its diagnostic horizons, as is characteristic of this class, providing high permeability to water, being able to be more easily well drained. Latossolos (Eutrustox) are suitable for use of annual, perennial, pasture and reforestation crops.

\subsection{Statistical Analysis}

According to the factorial loads of the chemical attributes and their respective eigenvalues, total observed and accumulated variances, the Factors 1, 2, 3 and 4 were obtained as main results, which explained $81.80 \%$ of the data variation, considering only the variables highlighted (Table 5).

Thus, we can conclude that the Factor 1, considered a factor of greater influence in the differentiation of soils under different systems of uses, is related to acidity. The soil acidity refers to its ability to release protons, passing from one state to another in relation to a reference (Jackson, 1963). This represents the potential acidity $(\mathrm{H}+\mathrm{Al})$, aluminum $\left(\mathrm{Al}^{3+}\right), \mathrm{V}, \mathrm{pH}$ and $\mathrm{ESP}$, where the former contrasts with the others. The increase in $\mathrm{pH}$ 
consequently leads to a decrease in $\mathrm{Al}$ activity; such increases in $\mathrm{pH}$ may have beneficial or deleterious effects on plant growth.

In alkaline or lime soils, increasing $\mathrm{pH}$ may lead to a lower availability of micronutrients, such as $\mathrm{Fe}, \mathrm{Mn}, \mathrm{Cu}$ and $\mathrm{Zn}$ (Souza, 2007). In acid soils, an increased $\mathrm{pH}$ may result in a decreased $\mathrm{Al}$ activity and, in some cases, $\mathrm{Mn}$ activity, as well as increased availability of some nutrients (Silva \& Mendonça, 2008).

The most important Factor 2 is represented by the basic cations $\mathrm{Na}^{+}$(sodium), $\mathrm{K}^{+}$(potassium), BS (Base Sum) and the Factor 3 by aluminum (Al) and aluminum acidity (m). We observed that both are related to soil fertility.

Base saturation is an excellent indication of general soil fertility conditions and is used to complement soil nomenclature. According to Melo et al. (1983) values of BS, CEC and V are of great importance in relation to soil fertility and the use of fertilizers and correctives. The dystrophic soil probably will be acidic and may affect crop development, which can be verified in the Latossolo (Eutrustox) (Profile 2).

Factor 4 relates the importance of the macronutrient $\mathrm{Ca}^{2+}$ found in a greater quantity in the studied soils. Higher amounts of calcium in this study were found in Cambissolo (Haplustepts) (Profiles 1 and 3) due to the geology of the regions, where these soils are classified as Cretaceous of the Apodi group, Jandaíra limestone and Arenito Açu. They also accumulate organic residues.

Table 5. Factorial loads of the chemical attributes of the analyzed soils and their respective eigenvalues, and total observed and accumulated variances

\begin{tabular}{lllll}
\hline \multirow{2}{*}{ Variable } & \multicolumn{3}{c}{ Factorial loads $^{(1)(2)}$} \\
\cline { 2 - 5 } $\mathrm{pH}$ Water & 1 & 2 & 3 & 0.31 \\
$\mathrm{EC}$ & -0.81 & 0.28 & 0.46 & 0.08 \\
$\mathrm{P}$ & -0.55 & -0.39 & 0.23 & 0.11 \\
$\mathrm{TOC}$ & 0.58 & 0.44 & 0.07 & 0.56 \\
$\mathrm{Ca}_{2+}$ & 0.57 & 0.25 & 0.12 & 0.92 \\
$\mathrm{~K}_{+}$ & 0.04 & 0.26 & 0.09 & 0.10 \\
$\mathrm{Na}_{+}$ & -0.04 & 0.74 & 0.06 \\
$\mathrm{Al}_{3+}$ & -0.27 & 0.87 & -0.08 \\
$(\mathrm{H}+\mathrm{Al})$ & 0.06 & -0.13 & 0.97 & 0.34 \\
$\mathrm{BS}$ & 0.85 & -0.17 & 0.10 & 0.43 \\
$\mathrm{~V}$ & -0.19 & 0.84 & 0.12 & 0.24 \\
$\mathrm{~m}$ & -0.82 & 0.30 & -0.96 & -0.06 \\
ESP & 0.07 & -0.12 & 0.23 & 1.05 \\
\hdashline Eigenvalue & -0.74 & 0.45 & 1.94 & 8.05 \\
Total variance $(\%)$ & 4.58 & 3.07 & 14.91 & 81.80 \\
Cumulated variance (\%) & 35.24 & 23.60 & 73.74 & 0.20 \\
\hline
\end{tabular}

Note. (1) Factorial loads obtained by the rotation of the varimax method (2) For the purpose of interpretation, factorial loads $\geq 0.70$ were considered significant.

The analysis of Figure 1, which represents the projection diagrams of the vectors for soil chemical attributes, confirms the influence of the chemical attributes to differentiate the soils using different systems.

The Factor 1, generated for the chemical attributes of the soil, explained $35.24 \%$ of the total variation of the attributes studied, and the highest correlation coefficients were identified for the variables $(\mathrm{H}+\mathrm{Al}), \mathrm{V}$ and $\mathrm{pH}$, that is, these attributes were more sensitive in the distinction of soil classes. 

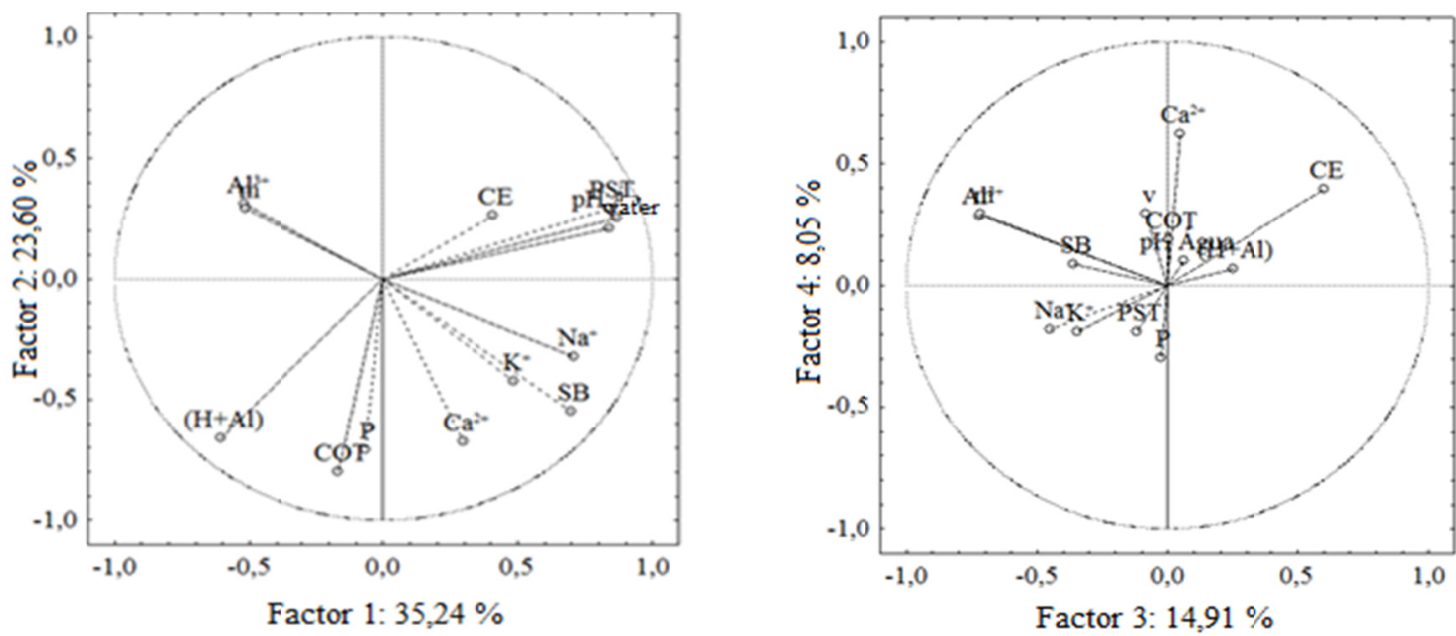

Figure 1. Vector projection diagrams for the chemical attributes of the studied soils

This can be seen in the vector projection diagram, where these attributes are more distant from the axis of the Factor 1.

For the Factor 2, where the explained variance was lower (23.60\%), the Na was identified as the most sensitive attribute for the distinction of the soils using different systems of use, presenting a greater distance of its vector in relation to the axis of the Factor 2. For the Factor 3, where the explained variance was $14.91 \%$, the $\mathrm{Al}$ was identified as the most sensitive attribute in land use distinction, showing a greater distance from its vector in relation to the Factor 3 axis. As for the Factor 4, where the explained variance was lower (8.05\%), only the $\mathrm{Ca}^{+}$ was identified as a sensitive attribute in the distinction of soils using different systems of use.

The analysis of dendrograms (Figure 2) showed the formation of distinct clusters for the soil attributes, which gathered variables that are related in determining the soil characteristic. At the homogeneity level of $80 \%$, two groups of classes of soil chemical attributes were observed, where the lowest dissimilarity was observed between the base sum and calcium and between $\mathrm{m}$ (acidity by aluminum) and $(\mathrm{H}+\mathrm{Al})$.

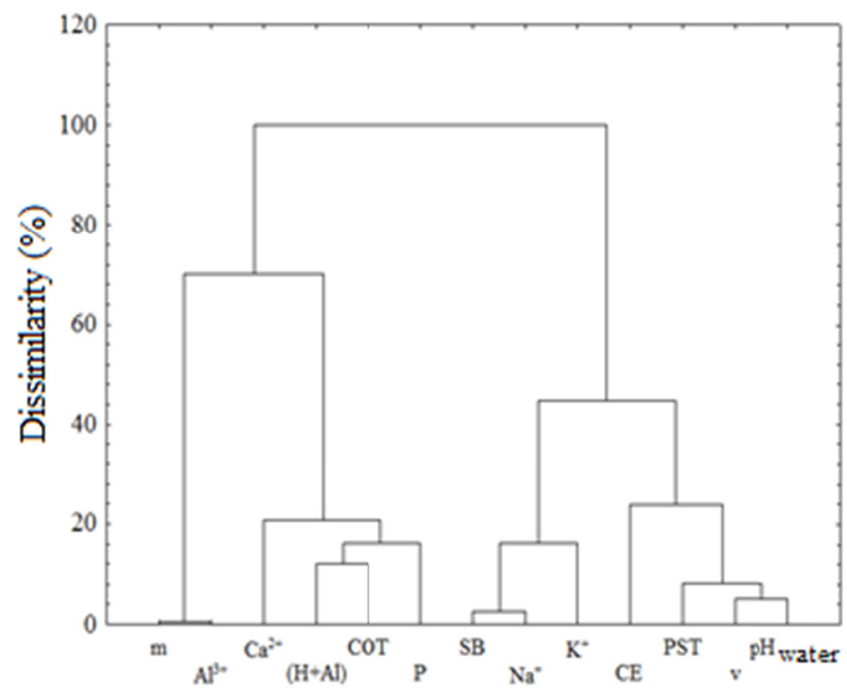

Figure 2. Dendogram of dissimilarity among the chemical attributes of the studied soils

Table 6 presents the results for physical attributes using criteria to determine the amount of factors sufficient for the analysis, taking into account those that explain at least $80 \%$ of the total variability of the data together with the eigenvalues, explanation of variances associated to the factors generated, and the explanation of the 
accumulated variances. Thus, as main results, Factors 1 and 2 explained $80.82 \%$ of the data variation, considering only the variables.

Table 6. Factorial loads of the physical attributes of the analyzed soils and their respective eigenvalues, and total observed and accumulated variances

\begin{tabular}{llc}
\hline \multirow{2}{*}{ Variable } & \multicolumn{2}{c}{ Factorial loads $^{(1)(2)}$} \\
\cline { 2 - 3 } & 1 & 2 \\
\hline Moisture & 0.89 & -0.35 \\
PL & 0.75 & -0.53 \\
PI & 0.93 & -0.32 \\
Coarse sand & 0.72 & 0.19 \\
Thin sand & 0.12 & 0.88 \\
Silt & -0.91 & 0.00 \\
Clay & 0.14 & -0.92 \\
Eigenvalue & 0.79 & 0.29 \\
Total variance (\%) & 4.42 & 2.04 \\
Cumulated variance (\%) & 55.29 & 25.53 \\
\hline
\end{tabular}

Note. (1) Factorial loads obtained by the rotation of the varimax method (2) For the purpose of interpretation, factorial loads $\geq 0.70$ were considered significant.

This shows the factorial loads of the physical attributes of the analyzed soils, their respective eigenvalues and total observed and accumulated variances, through which we can conclude that the Factor 1, considered a factor of greatest influence on the differentiation of soils under different systems of use, is related to soil consistency. It represents moisture, liquidity limit, plasticity, plasticity index, clay and thin sand, where the latter contrasts with the others.

The limits of liquidity and plasticity generally depend on the quantity and type of clay in the soil. The plasticity index, however, depends on cementing agents. In practice, the soil can be characterized by its plasticity index and its liquidity limit. In general terms, texture is one of the properties of the soil that most correlates with the manifestations of consistency.

Coarse textured soils are generally non-plastic and non-sticky when wet, friable when moist and loose when dry. Fine-textured soils are plastic and sticky when wet, firm when wet and hard when dry (Ranzani, 1969). As in the case of this study, the Latossolo (Eutrustox) (Profile 2) and Cambissolos (Haplustepts) (Profiles 1 and 2) soils with more sandy texture were classified as poorly plastic.

Factor 2 represents coarse sand, contrasting with silt. The analysis of Figure 3, which shows the projection diagrams of the vectors for the soil physical attributes, confirms the influence of the chemical attributes to differentiate the soils using different systems. 


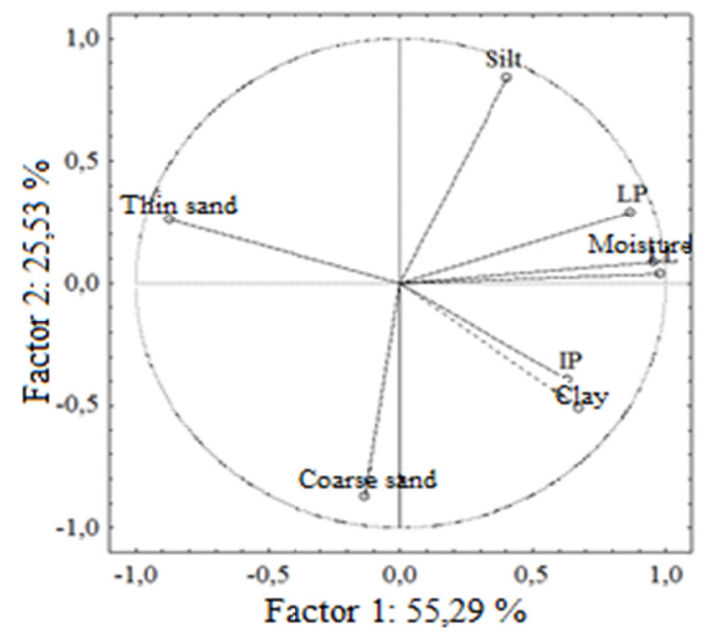

Figure 3. Vector projection diagrams for the physical attributes of the studied soils

The Factor 1, generated for the physical attributes of the soil, explained $55.29 \%$ of the total variation of the attributes studied, and the highest correlation coefficients were identified for the variables liquidity limit, moisture and thin sand, that is, these attributes were more sensitive in the distinction of soil classes. This can be observed in the vector projection diagram, where these attributes are more distant from the axis of the Factor 1. For the Factor 2, where the explained variance was lower $(25.53 \%)$, the silt was identified as the most sensitive attribute in the distinction of the soils under different systems of use, presenting a greater distance of its vector in relation to the axis of the Factor 2. It is worth mentioning that the silt is indicative of a young soil, presenting cerosity and susceptible to erosion.

The analysis of dendrograms (Figure 4) showed the formation of distinct clusters for soil attributes. They collected variables that worked related to the determination of the soil characteristic. Traced at the homogeneity level of $80 \%$, three groups of physical attributes are highlighted. One group gathers thin sand, the other coarse sand, clay and PI and the third group gathers silt, PL, LL and moisture. The lowest dissimilarity was observed between the Liquidity and Moisture Limit and the highest between coarse sand and plasticity index.

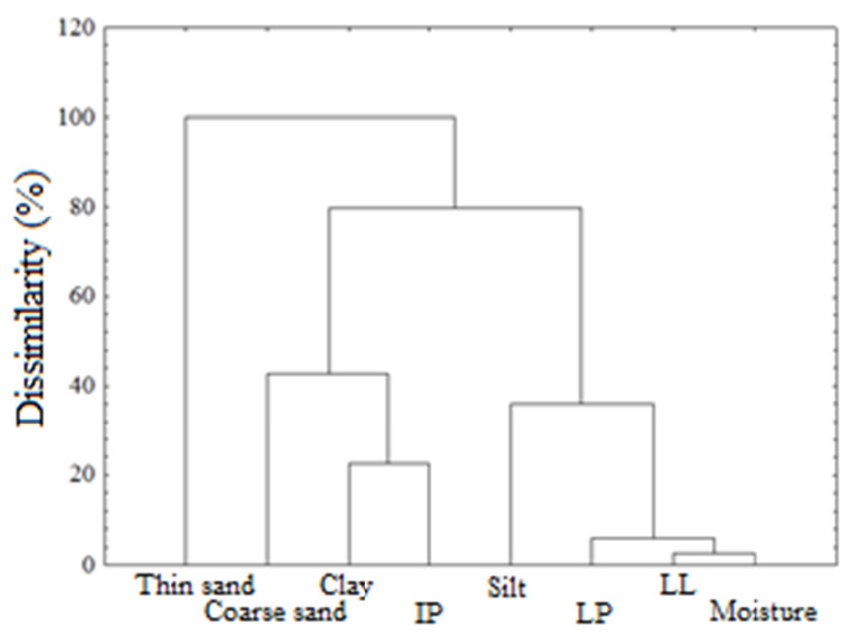

Figure 4. Dendogram of dissimilarity among the physical attributes of the studied soils

Table 7 shows the results for chemical together with physical attributes using criteria to determine the number of factors sufficient for the analysis, thus obtaining as main results the Factors 1, 2, 3, 4 and 5, which explained $82.85 \%$ of the variation of the data, considering only the variables. 
Table 7. Factorial loads of the chemical and physical attributes of the analyzed soils and their respective eigenvalues, and total observed and accumulated variances

\begin{tabular}{|c|c|c|c|c|c|}
\hline \multirow{2}{*}{ Variable } & \multicolumn{5}{|c|}{ Factorial loads $^{(1)(2)}$} \\
\hline & 1 & 2 & 3 & 4 & 5 \\
\hline Moisture & 0.83 & 0.11 & 0.15 & 0.36 & 0.22 \\
\hline PL & 0.72 & 0.32 & 0.00 & 0.45 & 0.23 \\
\hline LL & 0.82 & 0.09 & 0.14 & 0.32 & 0.41 \\
\hline PI & 0.52 & -0.35 & 0.29 & -0.04 & 0.49 \\
\hline $\mathrm{pH}$ Water & 0.19 & 0.78 & 0.32 & 0.25 & -0.01 \\
\hline $\mathrm{EC}$ & 0.02 & 0.64 & 0.37 & -0.35 & 0.25 \\
\hline $\mathrm{P}$ & 0.51 & -0.59 & 0.22 & 0.08 & 0.06 \\
\hline TOC & 0.14 & -0.55 & 0.08 & 0.17 & 0.61 \\
\hline $\mathrm{Ca}_{2+}$ & 0.37 & 0.05 & 0.07 & 0.15 & 0.86 \\
\hline $\mathrm{K}_{+}$ & 0.68 & 0.01 & -0.03 & 0.44 & -0.07 \\
\hline $\mathrm{Na}_{+}$ & 0.27 & 0.15 & 0.19 & 0.88 & 0.04 \\
\hline $\mathrm{Al}_{3+}$ & -0.22 & -0.12 & -0.90 & -0.02 & -0.06 \\
\hline$(\mathrm{H}+\mathrm{Al})$ & -0.06 & -0.78 & 0.16 & -0.27 & 0.45 \\
\hline BS & 0.44 & 0.14 & 0.15 & 0.76 & 0.35 \\
\hline V & 0.23 & 0.81 & 0.03 & 0.31 & 0.08 \\
\hline $\mathrm{m}$ & -0.19 & -0.13 & -0.88 & -0.03 & -0.04 \\
\hline ESP & 0.08 & 0.63 & 0.35 & 0.49 & -0.24 \\
\hline Coarse sand & -0.16 & -0.24 & 0.53 & -0.53 & 0.17 \\
\hline Thin sand & -0.61 & -0.01 & -0.56 & -0.22 & -0.35 \\
\hline Silt & 0.10 & 0.11 & -0.19 & 0.89 & 0.14 \\
\hline Clay & 0.78 & 0.11 & 0.39 & -0.34 & 0.07 \\
\hline Eigenvalue & 7.78 & 4.33 & 3.05 & 1.18 & 1.06 \\
\hline Total variance $(\%)$ & 37.03 & 20.63 & 14.54 & 5.62 & 5.04 \\
\hline Cumulated variance $(\%)$ & 37.03 & 57.66 & 72.20 & 77.82 & 82.85 \\
\hline
\end{tabular}

Noe. (1) Factorial loads obtained by the rotation of the varimax method (2) For the purpose of interpretation, factorial loads $\geq 0.70$ were considered significant.

This shows the factorial loads of the chemical and physical attributes of the analyzed soils, their respective eigenvalues and observed and accumulated total variances, with which we can conclude that the Factor 1, considered a factor of greater influence on the differentiation of soils under different systems of use, is related to moisture, PL, LL and clay, interpreting that for the differentiation of the land uses these physical attributes were more important than the chemical ones. Moisture governs the adhesion and cohesion forces of soils (consistency) influenced by the clay fraction.

The relation between these attributes in Cambissolos (Haplustepts) (Profiles 1 and 2) was noted, where there was an increase in the liquidity and plasticity limit due to the increase of the clay content, and also for the Latossolo (Eutrustox) (Profile 2) there was a decrease in these limits in function of the textural classification sandy loam and sandy (horizons $\mathrm{A}$ and $\mathrm{AB}$ ) and sandy clayey (BA and $\mathrm{B}$ horizon).

The Factor 2 is related to acidity through potential acidity $(\mathrm{H}+\mathrm{Al}), \mathrm{V}$ (Base Saturation) and $\mathrm{pH}$, where the former contrasts with the others. Factor 3 represents aluminum $\left(\mathrm{Al}^{3+}\right)$ and acidity by aluminum $(\mathrm{m})$. Factor 4 represents $\mathrm{Na}^{2+}$, BS (Base Sum) and silt. Finally, the Factor 5 relates to the importance of the macronutrient $\mathrm{Ca}^{2+}$ found in greater quantity in the studied soils.

The analysis of Figures 5 and 6, which shows the projection diagrams of the vectors for the soil physical attributes, confirms the influence of the physical and chemical attributes to differentiate soils using different systems. The Factor 1, generated for the chemical attributes of the soil, explained $37.03 \%$ of the total variation of the attributes studied, and the highest correlation coefficients were identified for the variables moisture and liquidity limit, that is, these attributes were more sensitive in the distinction under different systems. This can be observed in the vector projection diagram, where these attributes are more distant from the axis of the Factor 1. 


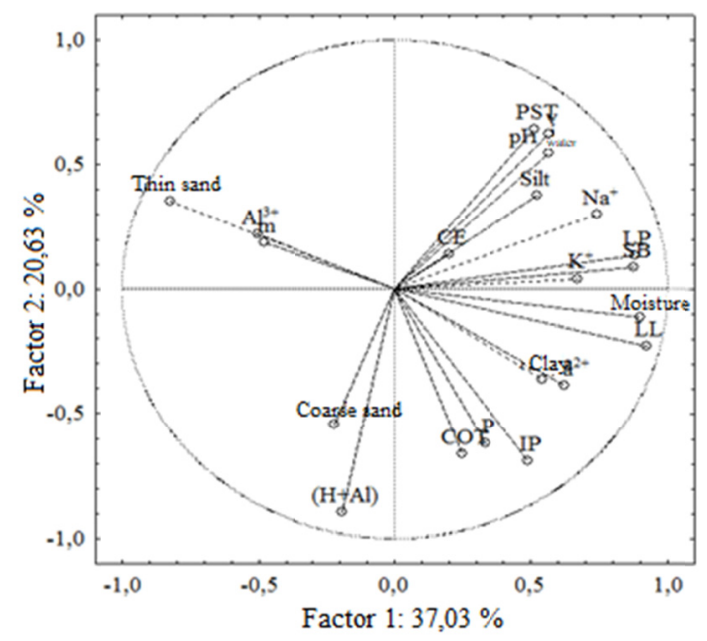

Figure 5. Vector projection diagrams for the chemical and physical attributes of the studied soils
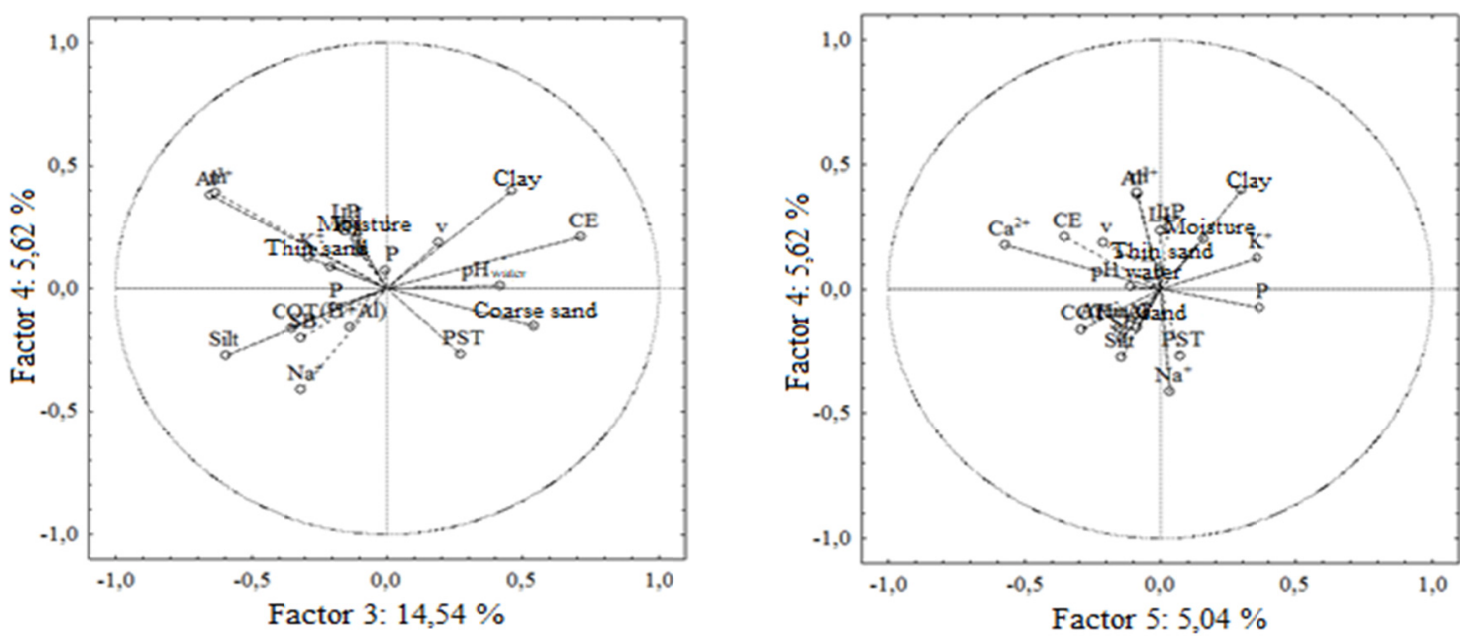

Figure 6. Vector projection diagrams for the chemical and physical attributes of the studied soils

For the Factor 2, where the explained variance was lower (20.63\%), the V was identified as the most sensitive attribute in the distinction of the soils under different systems of use, presenting a greater distance of its vector from the axis of the Factor 2. For the Factor 3, where the explained variance was $14.54 \%$, the $\mathrm{Al}$ was identified as the most sensitive attribute in the distinction of the soils under different systems of use, presenting a greater distance of its vector from the axis of the Factor 3. As for the Factor 4, where the explained variance was lower $(5.62 \%)$ and for the Factor $5(5.04 \%)$, only the Ca was identified as a sensitive attribute in the distinction of soils under different systems of use.

The analysis of the dendrograms (Figure 7) showed the formation of distinct clusters for the chemical and physical attributes of the soil, which gathered variables that worked related to the determination of the characteristics of the soils under different systems of use. Traced at the level of homogeneity of $30 \%$, two groups of classes were highlighted: one gathered physical particle size characteristics and the other physical and chemical attributes, showing less dissimilarity between thin sand and clay fractions. 


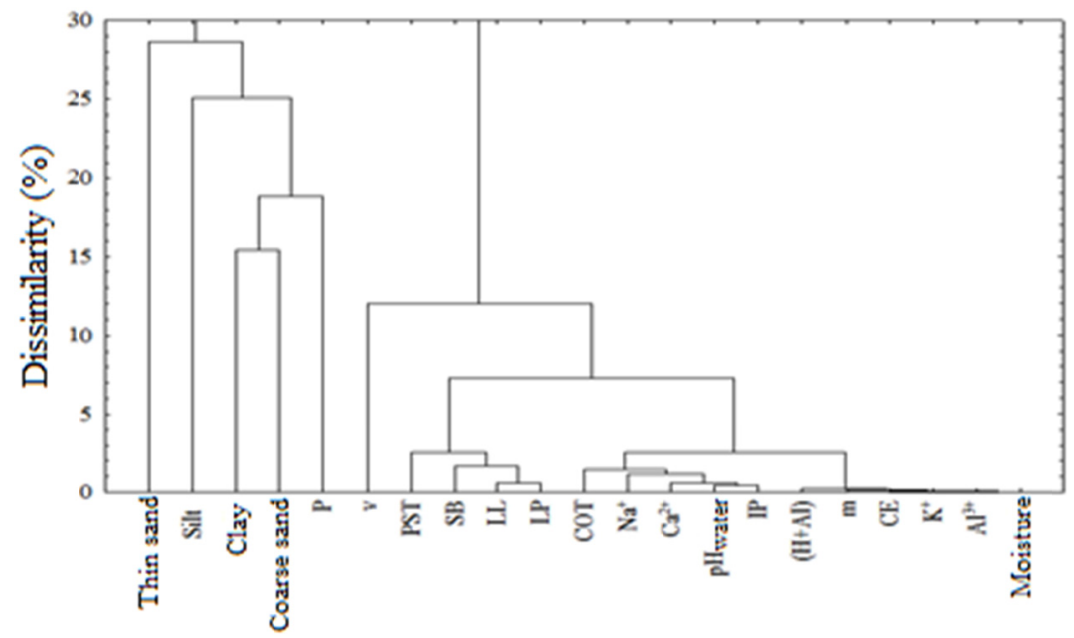

Figure 7. Dendogram of dissimilarity among the physical and chemical attributes of the studied soils

\section{Conclusions}

The physical attributes moisture, liquidity limit, plasticity limit, plasticity index, thin sand, clay, coarse sand and silt were indicators for the differentiation of soils under different systems of uses; however, moisture, liquidity limit, plasticity limit, plasticity index, clay, thin sand were the most sensitive.

The chemical attributes $\mathrm{pH},(\mathrm{H}+\mathrm{Al}), \mathrm{V}, \mathrm{ESP}, \mathrm{Na}, \mathrm{Al}$ and $\mathrm{Ca}$ were indicators for the differentiation of soils under different systems of use; however, $\mathrm{pH},(\mathrm{H}+\mathrm{Al}), \mathrm{V}, \mathrm{ESP}$ were the most sensitive.

The studied areas presented acidity reactions to alkalinity with presence of $\mathrm{Al}^{3+}$ and $(\mathrm{H}+\mathrm{Al})$ with a high salinity.

The source material favored an increase in calcium, sodium, magnesium and potassium contents.

The highest contribution of TOC was found in Cambissolo 2 (Haplustepts 2) due to the addition of the clay fraction.

Physical attributes have proved to be more influential than chemical attributes in the distinction of soils under different systems of uses.

\section{References}

Batista, M. de J., Novaes, F. de, \& Santos, D. G. dos. (2002). Drenagem como instrumento de dessalinização e prevenção da salinização de solos (2nd ed., p. 216). Brasília: CODEVASF (Série Informes Técnicos).

Beltrão, B. A., Rocha, D. E. G. A., Mascarenhas, J. C., Souza Júnior, L. C., Pires, S. T. M., \& Carvalho, V. G. D. V. L. G. D. (2015). Projeto cadastro de fontes de abastecimento por água subterrânea Estado do Rio Grande do Norte (1st ed., p. 10). Recife: CPRM/PRODEEM.

Buckman, H. O., \& Brady, N. C. (1989). Natureza e propriedade dos solos (5th ed., p. 647). Rio de Janeiro: Biblioteca Universitária Freitas Bastos.

Caputo, H. P. (1987). Mecânica dos solos e suas aplicações (6th ed., p. 219). Rio de Janeiro: Livros Técnicos e Científicos.

Coelho, M. R., Santos, H. G., Silva, E. F., \& Aglio, M. L. D. O. (2016). recurso natural solo. In C. V. Manzatto, E. F. Junior, \& J. R. R. Peres (Eds.). Uso agricola dos solos brasileiros (pp. 1-11). Rio de Janeiro: Embrapa Solo.

Empresa Brasileira De Pesquisa Agropecuária (EMBRAPA). (1997). Centro Nacional de Pesquisa em solos. Manual de métodos de análises de solo (2nd ed., p. 212). Rio de Janeiro: Embrapa.

Jackson, M. L. (1963). Aluminum bonding in soils: A unifying principle in soil science. Proceedings Soil Science Society of America, Madison, 27(1), 1-9. https://doi.org/10.2136/sssaj1963.03615995002700010 $008 \mathrm{x}$

Jacomine, P. K. T., Silva, F. B. R., Formiga, R. A., Almeida, J. C., Beltão V. de, Pessoa, S. C. P., \& Ferreira, R. C. (1971). Levantamento exploratório reconhecimento de solos do estado do Rio Grande do Norte (1st ed., p. 531). Recife: MA-DNEPEA: SUDENE-DRN. 
Kiehl, J. de C., \& Lambais, M. R. (1994). Fertilidade do solo (1st ed., p. 94). Piracicaba: USP/ESALQ.

Linhares, S., \& Gewandszbajder, F. (1998). Biologia Hoje (1st ed., p. 424). São Paulo: Ática.

Melo, F. de A. F. de, Brasil Sobrinho, M. de O. C. do, Arzolla, S., Silveira, R. I., Cobra Netto, A., \& Kiehl, J. de C. (1983). Fertilidade do solo (1st ed., p. 400). São Paulo: Nobel.

Meurer, E. J. (2000). Fundamentos de Química do Solo (1st ed., p. 174). Porto Alegre: Genesis.

Nogueira, J. R. L. R. (2000). Caracterização de solos degradados pela atividade agrícola e alterações biológicas após reflorestamentos com diferentes associações de espécies da Mata Atlântica (p. 50, Dissertação (Mestrado), Escola Superior de Agricultura Luiz de Queiroz/USP, Piracicaba, São Paulo).

Ranzani, G. (1969). Origem e desenvolvimento do solo (1st ed., p. 217). Piracicaba: O Autor.

Ribeiro, A. C., Guimarães, P. T. G., \& Alvarez Venegas, V. H. (1999). Recomendações para uso de corretivos e fertilizantes em Minas Gerais (5a Aproximação, 1st ed., p. 359). Viçosa: SFSEMG.

Ronquim, C. C. (2010). Conceitos de fertilidade do solo e manejo adequado para as regiões tropicais (1st ed., p. 26). Campinas: Embrapa Monitoramento por Satélite.

Santos, H. G., Almeida, J. A., Oliveira, J. B., Lumbreras, J. F., Anjos, L. H. C., Coelho, M. R., \& Oliveira, V. A. (2013). Sistema brasileiro de classificação de solos (3rd ed., p. 353). Brasília: Embrapa.

Santos, V. R., Moura Filho, G., Santos, C. G., Santos, M. A. L., \& Cunha, J. L. X. L. (2016). Contribuição de argilominerais e da matéria orgânica na ctc dos solos do Estado de Alagoas. Revista Caatinga, 22(1), 2009.

Silva, I. R. e Mendonça, E. S., \& Matéria, O. D. S. (2008). In R. F. Novais, V. Alvarez, N. F. Barros, R. L. F. Fontes, R. B. Cantarutti, \& J. C. L. Neves (Eds.), Fertilidade Do Solo (1st ed., pp. 275-374) Viçosa: Sociedade Brasileira De Ciência Do Solo.

Soil Survey Staff. (1999). Soil taxonomy: A basic system of soil classification for making and interpreting soil surveys (2nd ed., p. 436). Natural Resources Conservation Service. U.S. Department of Agriculture Handbook.

Souza, D. M. G., Miranda, L. N., \& Oliveira, S. A. Acidez Do Solo E Sua Correção. In R. F. Novais, V. V. H. Alvarez, N. F. Barros, \& R. L F. Fontes (2007). Cantarutti, R.B. e Neves, J.C.L. Fertilidade Do Solo (1st ed., pp. 205-274). Viçosa: Sociedade Brasileira De Ciência Do Solo.

StatSoft. (2004). Statistica Version 7.0. StatSoft. Retrieved from http://www.statsoft.com

Teixeira, P. C., Donagema, G. K., Fontana, A., \& Teixeira, W. G. (2017). Manual de Métodos de Análise de Solo (3rd ed., p. 575). Rio de Janeiro: Embrapa Solos.

\section{Copyrights}

Copyright for this article is retained by the author(s), with first publication rights granted to the journal.

This is an open-access article distributed under the terms and conditions of the Creative Commons Attribution license (http://creativecommons.org/licenses/by/4.0/). 